\title{
The Effect of the Discovery Learning Method On Students' Learning Results Understanding Speaking Materials
}

\author{
Yulianti Rasyid $^{1,{ }^{*}}$ Hermawati Syarif $^{1}$ Agustina $^{1}$ \\ ${ }^{I}$ Indonesian Language Department, Universitas Negeri Padang, Padang, Indonesia \\ ${ }^{*}$ Corresponding author. Email: yulianti_rasyid@fbs.unp.ac.id
}

\begin{abstract}
Research in tian aims to describe the effect of the use of methods of discovery learning to learning outcomes of the students to understand the material spelling. In lectures, many students have problems using spelling due to lack of knowledge and practice using spelling in writing. The discovery learning method was chosen because by finding the concept for yourself, the knowledge will stay longer in the student's memory. This research is an experimental research. From the results of the study concluded the following three things. First, student learning outcomes understand the spelling material using the discovery learning method are in Excellent qualification (BS). Second, student learning outcomes in understanding spelling material without using the discovery learning method are in the More Than Enough ( $\mathrm{LdC}$ ) qualification. Third, based on the results of hypothesis testing the discovery learning method has a significant effect on student learning outcomes in understanding the spelling material.
\end{abstract}

Keywords: Influence, Discovery learning, Learning outcomes, Spelling comprehension.

\section{INTRODUCTION}

Indonesian is not only used as the national language but is also used as the language of instruction in education. The use of the Indonesian language, both spoken and written, is regulated in the Indonesian language rules. In the variety of writings, Indonesian has undergone several changes in determining the rules of language. The use of written Indonesian is closely related to the use of spelling. Spelling is used so that the reader understands the message the author wants to convey. Indonesian is studied from elementary school to university level [1]. For higher education level, Indonesian is used to support academic assignments. The use of Indonesian in a variety of writings requires a good understanding of choosing words, arranging sentences, and using spelling. In learning, there are still many students who have difficulty understanding and using spelling in writing. There are three factors that make it difficult for students to understand and use spelling in writing. First, the factors in terms of students. Many students still find it difficult to distinguish the use and writing of prepositions. There are errors in the use of punctuation, letters, and writing words in the thesis. Second, the factors that are viewed from the teacher. In classroom learning there are still deficiencies in the emphasis and use of Indonesian in accordance with the material. Third, in terms of the environment. In terms of the environment, there is still a lack of correct use of Indonesian, which affects students' interest in justifying their mistakes in language [2][6] .

To be able to improve students' abilities in learning, innovations in the field of education can be utilized. One of them by utilizing learning models or methods in learning. based on research conducted by Nurlina [6], it was found that by using the IPJ (Inquiry in Journal) method there was an increase in students' ability to edit text. By using the IPJ method in learning, students' understanding and ability to work together increases. Another research was conducted by Suminar [13] by applying the learning model of discovery learning and problem based learning. The results showed that by using the discovery learning learning model can improve student achievement. The research conducted by Alimin [1] showed that by using the method of discovery learning there is an increase in student results in the course of sociolinguistics. Learning outcomes using the discovery learning method obtained an average value of 79.82 and had a significant effect on learning outcomes in transfer and code mixing 
materials. Therefore, this study chose to use the discovery learning method in determining student learning outcomes in understanding the spelling material.

The discovery learning method was developed by Jerome Bruner. The thing that forms the basis of $\mathrm{J}$. Bruner's idea is the opinion of Piaget which states that children must play an active role in learning in the classroom [3]. In the discovery learning method, the discovery is made by students. The discovery learning method focuses on the ability to solve problems through curiosity in finding things that are important in learning. In the discovery learning method, the material is not delivered in a final form. Students are encouraged to identify the information they want to know by searching and organizing the information they get in the form of a final conclusion. Learning outcomes using the discovery learning method are easier and faster for students to respond. This method can be used in other fields of study and is useful for improving students' ability to reason better [1],[5].

Based on the stated background, this study aims to describe the effect of the discovery learning method on student learning outcomes in understanding the spelling material. This study also describes student learning outcomes in understanding spelling material without using the discovery learning method applied in the control class. In addition, this study describes student learning outcomes in understanding spelling material using the discovery learning method applied in the experimental class.

\section{METHOD}

This type of research is quantitative research. This research is an experimental study using a two- group static design [12]. The two-group static design is a research design that uses two sample groups that are considered the same in all aspects, the difference being the treatment given to the experimental group. The population in this study were students who took general Indonesian courses in the 2020/2021 academic year. The sample in this study was two classes consisting of 40 students. One class will be used as a control class and the other class will be used as an experimental class. The instrument used in this study was an objective test consisting of 40 questions.

\section{RESULT AND DISCUSSION}

The research that has been conducted aims to describe the following three things. First, student learning outcomes understand the spelling material in the control class without using the discovery learning method . Second, student learning outcomes understand the spelling material in the experimental class using the discovery learning method . Third, the effect of using the discovery learning method on student learning outcomes to understand the spelling material.

Data on learning outcomes to understand the spelling material was obtained from an objective test of 40 questions. The question instrument was first tested to other classes to get valid and reliable questions. The instrument grid for the learning outcomes of spelling material is as follows. First, mastery of the use of letters which includes mastery of the use of capital letters and italics. Second, mastery of writing words and numbers. Third, mastery of the use of punctuation which includes periods, commas, and quotation marks. Fourth, mastery of writing absorption elements. The aspects assessed and the number of objective test questions for understanding spelling can be seen in the table below.

Table 1. Material Indicator Grid Understanding Spelling

\begin{tabular}{|c|l|c|}
\hline No. & \multicolumn{1}{|c|}{ Rated aspect } & $\begin{array}{c}\text { Number of } \\
\text { Questions }\end{array}$ \\
\hline 1 & writing letters & 11 \\
\hline 2 & Writing words and numbers & 10 \\
\hline 3 & Use of punctuation & 12 \\
\hline 4 & Writing absorption elements & 7 \\
\hline \multicolumn{2}{|c|}{ Number of Questions } & 40 \\
\hline
\end{tabular}

\subsection{Student Learning Outcomes Understanding Spelling Material in Control Class (Without Using Discovery Learning Method )}

Student results spelling understand the material without using discovery learning have the highest score is 35 and the lowest score 16 . The maximum score to be obtained by the students is 40 . The value of each indicator spelling understand the material can be seen from the table below 
Table 2. Score Recap for Spelling Understanding Indicator

\begin{tabular}{|r|l|c|c|}
\hline No. & \multicolumn{1}{|c|}{ Indicator } & Score & $\begin{array}{c}\text { Informatio } \\
\text { n }\end{array}$ \\
\hline 1. & Lettering & 88.74 & Very well \\
\hline 2. & $\begin{array}{l}\text { Writing words and } \\
\text { numbers }\end{array}$ & 89.53 & Very well \\
\hline 3. & Use of punctuation & 84.88 & Well \\
\hline 4. & $\begin{array}{l}\text { Writing absorption } \\
\text { elements }\end{array}$ & 87.91 & Very well \\
\hline
\end{tabular}

Student learning outcomes in understanding spelling in the control class have an average score of 74.83 with more than adequate qualifications. For indicators of understanding the use of letter writing in writing, an average score of 74.86 indicates that students are able to determine how to place good letter writing in writing. For indicators of understanding the writing of words and numbers in writing, an average score of 80.33 indicates that students are able to determine how to write words and numbers correctly in writing. For indicators of understanding the use of punctuation in writing, an average score of 63.44 indicates that students have not been able to determine how to place the correct use of punctuation in writing. For indicators of understanding the writing of absorption elements in writing, an average score of 80.72 indicates that students are able to determine how to write the correct absorption elements in writing. So, it can be concluded that students in the control class already understand the spelling material and use spelling in writing.

\subsection{Student Learning Outcomes Understanding Spelling Material in Experiment Class (Using Discovery Learning Method)}

Student learning outcomes in understanding spelling material using the discovery learning method overall have the highest score of 38 and the lowest score of 21. The maximum score that students must obtain is 40 . The value of each indicator of understanding spelling material can be seen from the table below.
Table 3. Score Recap for Spelling Understanding Indicator

\begin{tabular}{|r|l|c|c|}
\hline No. & \multicolumn{1}{|c|}{ Indicator } & Score & $\begin{array}{c}\text { Informat } \\
\text { ion }\end{array}$ \\
\hline 1. & Lettering & 74.86 & $\begin{array}{c}\text { More } \\
\text { than } \\
\text { enough }\end{array}$ \\
\hline 2. & $\begin{array}{l}\text { Writing words } \\
\text { and numbers }\end{array}$ & 80.33 & Well \\
\hline 3. & $\begin{array}{l}\text { Use } \\
\text { punctuation of }\end{array}$ & 63.44 & Enough \\
\hline 4. & $\begin{array}{l}\text { Writing } \\
\text { absorption } \\
\text { elements }\end{array}$ & 80.72 & Well \\
\hline
\end{tabular}

Student learning outcomes in understanding spelling in the control class have an average score of 87.76 with a qualification of Very Good. For indicators of understanding the use of letter writing in writing, the average score is 88.74 which indicates that students are able to determine how to place good letter writing in writing. For indicators of understanding the writing of words and numbers in writing, an average score of 89.53 indicates that students are able to determine how to write words and numbers correctly in writing. For indicators of understanding the use of punctuation in writing, an average score of 84.88 indicates that students are able to determine how to place the correct use of punctuation in writing. For indicators of understanding the writing of absorption elements in writing, an average score of 87.91 indicates that students have been able to determine how to write the correct absorption elements in writing. So, it can be concluded that students in the experimental class already understand the spelling material and know how to use spelling in writing.

\subsection{The Influence of the Discovery Learning Method on Student Learning Outcomes Understanding Spelling Materials}

Judging from the test results given to students, the test results using the discovery learning method were higher than the test results without using the discovery learning method. The results of the posttest were also higher than the results of the pretest that had been done previously. This is evident from the results of research showing that learning outcomes using the discovery 
learning method are in the qualification of Very Good (BS) with an average value of 87.76 , while learning outcomes without using the discovery learning method are in the qualification More than Enough (LdC). with an average value of 74.83. Likewise with the results of hypothesis testing which shows that $\mathrm{t}$ count is greater than $t$ table $(2,86>1,66)$ with a significance level of $95 \%$. This shows that the use of the discovery learning method has a significant effect on student learning outcomes in understanding the spelling material. The recapitulation of test results can be seen in the table below

Table 4. Recapitulation of Student Learning Outcomes Understanding Spelling

\begin{tabular}{|c|c|c|c|}
\hline Group & Pretest & Posttest & \multirow{3}{*}{$\begin{array}{c}\mathrm{t}_{\text {count }} \text { is } \\
\text { greater than } \\
\mathrm{t}_{\text {table }}( \\
2.86>1.66)\end{array}$} \\
\hline $\begin{array}{l}\text { Control } \\
\text { Class }\end{array}$ & 70,12 & 74.83 & \\
\hline $\begin{array}{l}\text { Experiment } \\
\text { Class }\end{array}$ & 80.23 & 87.76 & \\
\hline
\end{tabular}

The discovery learning method has a significant effect on student learning outcomes in understanding the spelling material because this method prioritizes active student learning and finds their own learning concepts [3][14]. The application of the discovery learning method in classroom learning is as follows. First, stimulation. At this stage students are faced with problems that raise questions. In this step, the lecturer gives a piece of writing that has spelling errors in it. This stage serves to help students develop and explore materials [7][11][15]. Second, identify the problem. At this stage, the lecturer invites students to collect problems relevant to learning and formulate hypotheses. At this stage, students are asked to determine the problem in the writing given whether there are errors in the use of spelling, diction, and sentences [7][11][15]. Third, data collection. At this stage, students are asked to collect relevant information to prove the hypothesis. This stage serves to answer questions and prove hypotheses. This stage helps to improve students' cognitive and memory because it combines five activities at once such as collecting literature, discussion, direct observation, presentation, and [4] [7][11][15].

The fourth stage in the discovery learning method is data processing. At this stage, students begin to collect spelling errors in writing according to the indicators that have been studied. Students begin to determine the spelling errors for each indicator into a table accompanied by evidence. This stage serves as concept formation and generalization [7][15]. Fifth, proof. At this stage, students conduct a careful examination to prove the established hypothesis with alternative findings and the results of data processing. At this stage students re-examine each answer that has been written by giving a check mark for each indicator [7][15]. Sixth, make conclusions. At this stage, conclude the learning process. At this stage, students understand the spelling material, know spelling mistakes, and correct spelling mistakes in writing. By applying the discovery learning method, it has helped students to hone their critical thinking skills, foster self-confidence, and help students to explore their own abilities in learning [1][4][7].

\section{CONCLUSION}

Based on the results and discussions that have been described previously, three things can be concluded as follows. First, results of student learning in the classroom spelling understand the material control without using discovery learning obtain an average value of 74,83 with the qualification More than Enough (LDC). Second, student learning outcomes in understanding spelling material in the experimental class using the discovery learning method obtained an average score of 87.76 with a Very Good (BS) qualification . Third, based on the results of the t-test, obtained $t$ count $>t$ table $(2,86>1,66)$ at the $95 \%$ significance level. Thus, it can be concluded that the use of the discovery learning method has a significant effect on student learning outcomes in understanding the spelling material. Based on the results and discussion in this study, there are several suggestions as follows. First, before deciding to use the discovery learning method, you should pay attention to the characteristics of the student/student to be studied. Second, this research can be used as a reference or comparison for similar research and this research can be further investigated in other fields for further research.

\section{ACKNOWLEDGMENTS}

The title "ACKNOWLEDGMENTS" should be in all caps and should be placed above the references. The references should be consistent within the article and follow the same style. List all the references with full details. 


\section{REFERENCES}

[1] Alimin. (2021). The Influence of the Application of the Discovery Learning Method on Learning Outcomes in Code Switching and Code Mixing Materials. Journal of Indonesian Language and Literature Education. 6(1).

[2] Fauzi. (2019). Analysis of Spelling and Sentence Errors in Thesis of Universitas Brawijaya Students as a Basis for Determining Strategies, Objectives, and Teaching Materials for Indonesian Language Courses at Universitas Brawijaya. Bahastra: Journal of Indonesian Language and Literature Education. 4(1).

[3] Hosnan. (2014). Scientific and contextual approaches in 21st century learning. Bogor: Ghalia Indonesia.

[4] Jaharuddin. (2020). The Influence of the Discovery Learning Model on Biology Learning Outcomes for Semester VI UNIMUDA Sorong Students in 2019. Biolearning Journal. 7(1).

[5] Mubarok \& Sulistyo. (2014). Application of the Discovery Learning Learning Model to the Learning Outcomes of Class X TAV Students on Competency Standards for Installing Sound Systems at SMK Negeri 2 Surabaya. Journal of Electrical Engineering Education.3.

[6] Nurlina. (2018). The Effectiveness of the IPJ Method (Inquiry in Journals) to Improve the Editing Ability of 5th Semester Students PBSIUMP, URECOL.

[7] Nurrohmi. (2017) . The Influence of Discovery Learning Learning Model on Students' Critical Thinking Ability. Journal of Education: Theory, Research, and Development. 2(10).

[8] Sinambela. (2013). 2013 Curriculum and Its Implementation in Learning. Campus Generation Journal. 6(2).

[9] Sudjana. (2007). Statistical Methods . Bandung: Tarsito

[10] Suminar. (2016). The Influence of Discovery Learning and Problem Based Learning Models on Student Achievement. Journal of Office Management Education. 1(1).
[11] Suprihatiningrum, J. (2013). Learning strategies, theories and applications. Yogyakarta: Ar-Ruzz Media

[12] Shah. M. (2004). Educational psychology with a new approach. Bandung: PT. Remaja Rosdakarya. 